\title{
REVIEW
}

\section{A Constitutional Law for the Age of Anxiety}

Ideals, Beliefs, Attitudes, AND the LAw; by Guido Calabresi. $\dagger$ Syracuse: Syracuse University Press, 1985. Pp. xv, 208. $\$ 20.00$ cloth, $\$ 11.95$ paper.

\section{Reviewed by Kathryn Abrams $\ddagger$}

Mephistopheles is alive and well. Those with doubts need only consult Ideals, Beliefs, Attitudes, and the Law, by Guido Calabresi. Making a deal with the devil-or "accepting the gift of the evil deity"-has becoine Calabresi's nietaphor for the tradeoffs faced by society in regulating technological progress or allocating scarce resources. A society which permits the use of automobiles, to take a familiar example, "accepts" the cost of many thousands of accident deaths per year. ${ }^{1}$ The diabolic inetaphor is also associated with the legal and pohtical subterfuges through which society shields its niembers froni the fact that it is willing to pay the human price for those benefits which make life easier or more pleasant for its remaining nuembers.

In this book, Calabresi pursues these themes into the field of constitutional law, where trade-offs are niore often expressed in conceptual than niaterial terms. With respect to thorny issues such as affirmative action or campaign spending, embracing one constitutional value seems to threaten the rejection of another. Yet far fron giving the devil his due, Calabresi seems intent on denying him his place in the machinery of constitutional choice. Taking the example of abortion, which one would assume to be among the most intransigent examples of value conflict, Calabresi argues that constitutional decisions can be niade in ways which avoid the sacrificc of either competing value (pp. 98-114). This resnlt, nioreover, appears to be achieved without rehance on the type of subter-

$\dagger$ Dean and Sterling Professor of Law, Yale Law School.

A Associate Professor, Boston University. B.A. 1980, Harvard College; J.D. 1984, Yale Law School. I would like to thank Ron Wright, Chip Lupu, Jack Beermann, Larry Yackle, Clay Gillette, Joe Singer, and Erwin Chemerinsky for their thoughtful comments on a draft of this review.

1. As Calabresi notes in an earlier work:

[W] build a tunnel under Mont Blanc because it is essential to the Common Market and cuts down the traveling time from Rome to Paris, though we know that about one nian per kilometer of tunnel will die. We take planes and cars rather than safer, slower means of travel. And perhaps nost telling, we use relatively safe equipment rather than the safest imaginable because-and it is not a bad reason-the safest costs too much.

G. CALABRESI, THE CostS OF ACCIDENTS 17-18 (1970). 
fuge which has become central in other areas of law. While this is a provocative-and refreshingly optimistic-thesis, the difficulties that accompany its execution suggest that the devil inay, in the end, have the last word.

\section{I}

\section{Oh, What a Paradise It Seems}

Calabresi does not begin with constitutional law, but takes his bearings from the field of tort. The ways in which behiefs and attitudes are imtegrated into common law rules, he suggests, provide important clues to the resolution of value conflict in the constitutional area. Taking "reasonableness" as the standard of behavior which determines liability in tort, he examines three types of circumstances in which behiefs or attitudes shape what the law declares to be "reasonable" behavior in tortfeasors and victims (pp. 21-86).

In the first set of circuinstances, forms of behavior that cause unusual risks to the actor or others are attributable to handicap, age, gender, race, or ethricity. Society must determine whether to place the cost of the ensuing accidents on the individual possessing the attribute or to allocate such costs to others (pp. 21-44). Tort law easily handles some departures, such as those caused by handicap: the standard of reasonable behavior $m$ the victim is adjusted to take account of handicap (pp. 2526), while disabled mjurers are held to a nonadjusted standard of reasonable behavior, $\mathrm{m}$ order to imternalize the costs of participation in hazardous activities (pp. 33-34). Other forms of behavior, such as those correlated with ethinicity or race, present greater difficulties. Calabresi highlights society's ambivalent response to the fact that drivers of certain ethnic and racial groups seem to have a disproportionately greater number of accidents than others. He notes that inany state laws prohibit the use of insurance classifications based on race or national origin, reflectimg a desire to put an end to discriminatory practices (p. 35). But he observes that $i m$ the face of such laws, many insurance compamies have begun to use proxies for these classifications, such as location of residence or occupation, thus permitting some discrimination to continue (p. 36).

In the second category of circumstances, an actor behaves in ways which might be described as idiosyncratic or uureasonable because he holds certain rehigious or quasi-rehioious behiefs (pp. 45-68). A Christian Scientist exacerbates the physical damage caused by an automobile accident by refusing to seek prompt medical treatment (p. 46); an unmarried, orthodox Jewish woman throws herself from a stalled skilift to avoid being trapped in an inaccessible place with a man after sundown (p. 51). Calabresi explaims that, influenced by the "gravitational pull" of the 
Establishment Clause, tort law lias permitted full recovery by such victims, no matter how idiosyncratic their beliefs (p. 60). This constitutionally favored parity among religious beliefs lias not extended to cases in which the injurer's action is caused by such beliefs. There the costs are permitted to lie where they fall —on the victim-only if the belief enjoys widespread acceptance (p. 64). Tort law employs a similar principle, Calabresi notes, in cases involving certain other quasi-religious or secular beliefs: even victims can recover only if their behiefs enjoy some measure of social acceptability (pp. 59-60).

In the third group of cases, the victim sustains some unusual degree of damage because of nonreligious sentiments or beliefs he holds (pp. 6486). A watch that is damaged in an accident turns out to have tremendous sentimental value to its owner (p. 70); an automobile wreck whicl1 claims several lives inflicts emotional anguish on a sensitive passerby (p. 70). Calabresi identifies several reasons why such sentinents rarely are recognized in tort recovery. It may be that the individual with an idiosyncratic attachment to a particular possession is in a better position to protect that possession than is the potential tortfeasor, who knows nothing about its sentimental value (pp. 73-74). Or society may believe that some sentiments, such as extreme emotional disturbance over the misfortunes of strangers, should not be encouraged by an award of damages (pp. 77-78). The law, as Calabresi observes in this section, has the power not ouly to reflect but also to transform beliefs and attitudes.

Despite the deft and often liumorous handling of these cases, one may first suspect that Calabresi has headed out in the wrong direction. The torts cases seem sufficiently distinct to form a dubious basis for a constitutional discussion. Conflicts in the field of torts most often juxtapose the preservation of beliefs and the imposition of costs. I am injured and inust pay substantial doctor's bills, to take one of Calabresi's less probable examples (p. 63), because your religion bids you jump off a ski lift and you land on my back. Society must determine the extent to which it wishes to encourage your religious beliefs, just as it would in a constitutional case. But because the burden imposed upon me, the competing claimant, is primarily economic, these cases present more limited problems of compensability than do constitutional cases. Society could, for example, establish a fund to which all contribute, which would be used to compensate those injured by behavior attributable to valued beliefs (pp. 66-67). Thus no individual would be obliged to bear the cost of protecting such beliefs. ${ }^{2}$

In contrast, $i m$ the constitutional area-and with respect to the abor-

2. Calabresi appears to concede that such cases are distinguishable when he states "[t]be fact that such a solution is feasible, even though we have not chosen to avail ourselves of it, means that the cases we have been discussing are not likely to be searing ones for our society" (p. 67). 
tion question in particular-conflicts tend to pit one belief against anotlier. Your riglit to practice your religion as you see fit interferes, for exainple, with iny right to be free of the state-supported establishment of rehigion. If a court supports the town in which we both live in permitting you to erect a crèche in our public square, I suffer not the diminution of iny incoine but the violation of iny beliefs. Even if I were entitled to recover froin a fund collected for victims of the exercise of selected rehigious behiefs, this would be insufficient to coinpensate ine for the dainage sustained. The money could not repair the injury to iny beliefs the way it could repair, for exanple, the injury to iny ribs; and I miglit, inoreover, be offended by the atteinpt to place a dollar value on iny inoral and pohtical beliefs.

In otler respects, however, Calabresi's examination of the tort law regime seems likely to contribute to his constitutional discussion. His three categories highlight three human attributes-attitudes toward disfavored groups, rehigious beliefs, and nonrational einotional commitinents-which promise to play a pivotal role in the abortion conflict, even if soine of the issues imvolved in their reconciliation are different. Moreover, many of the lessons Calabresi draws from the tort cases seein equally applicable to the constitutional sphere. Of central importance, first, is the power of law to effect changes in the inoral order of a society. In the realm of tort, the protection of idiosyncratic beliefs among victims, and the refusal to compensate the emotional anguish of passersby in an accident, reflect an effort to encourage or transform attitudes and beliefs. This view of law as an agent of transformation seems even inore applicable to the constitutional field, where conteinporary decisions in such areas as due process and desegregation have had a powerful transformative effect on public attitudes. Second, Calabresi warns of the tendency of our legal order to demand attitudinal hoinogeneity as the price of equality. While he inakes his point with the speculative exainple of driving styles and insurance rates (pp. 27-28), the argument has far greater saliency in comection with selective prosecution, state interference witlı rehigious "sects," and other constitutional cases.

Finally, Calabresi identifies a variety of rhetorical and institutional devices which inay be used to express societal anbivalence concerning a particular belief or value. Though a behef may be disfavored in some circumstances, society may nonetheless wish to preserve it and to reassure its proponents of its continuing value. This result may be aclieved through doctrimal compromises (highly idiosyncratic religious practices are considered reasonable in a tort victim but not in a tortfeasor) or by relying on a value external to the conflict, such as cost-avoidance, to resolve the case. Of particular efficacy in managing the inevitable coinpromises are legal subterfuges (also described as "he[s]" (p. 60) and 
"wishful thinking" (p.43)) which mute or hide a conflict in values to prevent it from having a divisive effect on the public. One example of such a subterfuge is the combination of a statutory "ban" on discrimination in the insurance industry with the actuarial use of proxies for proscribed classifications. The legislative prohibition permits an altered form of invidious classification to continue, but reminds the public of the importance of the antidiscrimination principle in American law (pp. 42-43). Another example is the submission of cases involving idiosyncratic beliefs to a jury, which can use the general verdict to resolve the case without making a permanent statement about the value of the belief in question (pp. 47-48). In some cases these subterfuges inay be the product of a willful effort to deceive, but in most, Calabresi suggests, the choices are so painful that decisionmakers cannot bring themselves either to select one value or to recognize the contradictions implicit in the arrangements they enact (pp. 32, 44, 116-17).

This last set of devices assumes center stage as Calabresi turns to value-on-value conflict. In a brief but crucial transitional passage which explores value conflict in nonconstitutional areas, Calabresi offers two mstructive examples. Many controversial euthanasia cases are resolved through an approach Calabresi describes as subterfuge. Although a judge inay have hittle doubt as to the samity of the accused, she issues an instrnction on the insamity defense (or soine other traditional defense which offers an excuse for the act in question) (p. 89). This instruction provides the jury with a ground for acquittal which does not require it to address the real issue of whether "inercy killing" is justified, and the general verdict permits it to shield the basis of its verdict. In the area of products hability, companies are expected to perform cost-benefit calculations in deciding which safety measures to implement; yet the public rebels at the thought of placing a dollar value on human hife (p. 89). These values are accominodated through a compromise-cost-benefit calculations which assign a value to liuman he are made routinely but always sub silentio-which is carefully policed by the jury system. The extraordinary damages awarded by the jury in the Ford Pinto case, Calabresi notes, reflect the jury's horror at Ford's clann that the level of safety attained was appropriate given the value which had been assigned to human hife. ${ }^{3}$

Calabresi so effectively highlights the advantages of subterfuge in the common law area, that it is startling to see him reject this expedient as he turns to constitutional law. Yet he condemns as a failure the subterfuge atteinpted by the Court in Regents of the University of California

3. Pp. 89, 184 n.322; see Grimshaw v. Ford Motor Co., 119 Cal. App. 757, 174 Cal. Rptr. 348 (1981). 
v. Bakke: ${ }^{4}$ that race-conscious admissions geared to the goal of diversity can pass constitutional muster where numerical quotas, which serve a similar purpose and can produce the same results, cannot (p. 90). Calabresi's explanation is that "diversity" lacks longstanding as a constitutional value, and an admissions board lacks the representative character of a jury. This clami seeins pretextual, given the similarity of the analysis to the use of "suspect" proxies in the insurance industry. Yet this discussion turns out to be a rehable portent of the approach to come, wherein Calabresi also criticizes the Court's opinion in Roe v. Wade ${ }^{5}$ as a subterfuge which should not have been atteinpted (pp. 92-93).

Calabresi faults Roe not only for einploying a fiction-the fetus is not a person for fourteenth amendment purposes-which he claims has slim support in constitutional and related private law jurisprudence. $\mathrm{He}$ also argues that Roe demes any constitutional basis to the position of the losing parties, and adds the insnlt of "emargination" to the injury of their loss (pp. 93-96). In cases involving constitutional value conflict, courts should strive to assure losing parties that their values reinam an important part of the constitutional landscape, even if they cannot be given priority or effect in a given case. Only after elaborating and affirming constitutional support for both values at issue in a conflict should a court make a choice between them; and this choice should be sufficiently provisional as to permit a change if it later becomes possible to accoinodate both values (pp. 97-98). This solution, Calabresi argues, prevents feelings of exclusion among the losing parties and more accurately mirrors the "strong tugs" (p. 98) that each party feels towards the values expressed by the other. Perhaps because of this latter feature, Calabresi identifies this type of approach as the "honest" solution (p. 116). He claims it is generally to be preferred to approaches involving dissimulation or subterfuge.

Calabresi concludes that an "honest" solution is possible, and should have been atteinpted, in the context of the abortion conflict. The Court should have identified and affirmed the Constitution's support for both values he describes as being at stake in the controversy: the right to protect life in all its forms and the equal right of woinen to unencumbered sexual freedom (p. 99). And in deciding in favor of the rights of women, it should have avoided derogating the constitutional position of the competing right and left open the possibility of a different resolution in the future.

4. 438 U.S. 265 (1978) (university admissions program employing quotas to admit students on basis of race violates equal protection). Calabresi discusses the failings of the Bakke opinion at greater length in Calabresi, Bakke as Pseudo-Tragedy, 28 CATH. U.L. REV. 427 (1979).

5. 410 U.S. 113 (1973) (state law prohibiting abortion infringes wounan's right to privacy). 
II

\section{Tragic Choices}

It is disconcerting to see the primary exponent of the Faustian legal bargain transformed into an unblemished optimist. Yet Calabresi is long on wishful strategies for conciliation and short on frank assessinents of costs. That the book is offered as an mitial approach to an intransigently coinplex problein (pp. xv, 108-09) inay provide some explanation. But as Calabresi proposes, however politely, that we modify our approach to the abortion question and other conflicts between constitutional values, readers are entitled to examine some of the costs before deciding whether his is a bargain our legal system should accept.

The first consequence of this approach for the abortion conflict itself would be a stark alteration in the terms of the debate. Calabresi admits that his characterization of the conflict presents both the life value and the equality value in "somewhat weakened" forms (p. 102). But while the weakening of the former value is attributable to the ambiguous character of fetal life, the weakening of the latter is Calabresi's own doing: his is surely the inost modest claim that has ever been inade for the prevailing side of the debate. Perhaps inore importantly, it is ill-suited to its assigned purpose. Alienation annong the pro-life forces would hardly be mitigated by a declaration that, while life is an important value in the constitutional scheme, it must in this case give way to sexual freedom. Some members of this group oppose even the dissemination of birth control, on the ground that its availability encourages proumscuity. ${ }^{6}$ Even conteinplating the conflagration that would result from the articulation of Calabresi's values casts the Supreme Court's "subterfuge" im a Solomomic glow.

The most important defects of Calabresi's redefinition, however, are not instrumental but analytic. He divorces the value of equal access to sexual freedom from values such as autonomy or privacy which are frequently associated with the pro-choice position, stating that the latter values have rarely prevailed in conflicts with other constitutional primciples (pp. 100-01). ${ }^{7}$ This perimits Calabresi to avoid potentially awkward references to "penumbrae" and "elnanations," and to sidestep a variety

6. See Schwartz, Bitter Pill, The New Repubuic, Feb. 18, 1985, at 11 (quoting Joseph Scheidler, head of Pro-Life Action League) ("I think contraception is disgusting . . . just mutual masturbation, people using each other for pleasure.").

7. Calabresi's categorical denial is cast into doubt by such important decisions as Eisenstadt v. Baird, 405 U.S. 438 (1972) (state law prohibiting, inter alia, dissemination of contraception to uninarried persous violates individual privacy protected by Constitution); Griswold v. Comecticut, 381 U.S. 479 (1965) (state law prohibiting prescription or use of contraceptives violates inarital privacy protected by Constitution); Hardwick v. Bowers, 760 F.2d 1202 (11th Cir. 1985) (en banc) (state sodomy law infringes upon individual privacy protected by Constitution).

8. See Griswold v. Connecticut, 381 U.S. at 484 ("specific guarantees in the Bill of Rights 
of issues, from mandatory birth control to the right of parents to deny treatment to neonates, which follow from the recognition of parental autonomy (p. 113). ${ }^{9}$ But this minimalism weakens the contested value to the point of implausibility. While there may be some who believe that unencumbered access to sex is a good comparable to life itself, this "Looking for Mr. Goodbar" hierarchy of value is certainly not shared by many. The reason that sexual freedoin is important, and raises critical issues of equality when it is demed to women, is that the riglit to use one's body to express intimacy or experience pleasure raises questions of self-determination. Women ought to enjoy equal access to sex for many of the same reasons that they ought to enjoy equal access to the workplace: because witlout the right to use one's body or mind and direct one's course in those noninjurious ways as one sees fit, life becomes infimitely less valuable. ${ }^{10}$

One might accept these flaws in Calabresi's solution to the abortion problein if his larger jurisprudential approach appeared sound. But here, too, there is little reason to be sanguine. Our suspicions are aroused by the fact that Calabresi gives little indication of low his approach would work. It is no mean feat to endorse botll contested values in an opimion which, by its nature, inust make a decisive choice between thein. The reader, quite reasonably, wonders how such an opinion would look, and Calabresi's answer does not reassure. He offers no explanation of low the courts should proceed froin the endorseinent of botli values to the choice of one. The inost concrete reference beyond Calabresi's discussion of the abortion question is his suggestion that the Japanese exclusion

have penumbras, formed by emanations from those guarantees that help give them life and substance.").

9. Calabresi's disavowal of privacy and the related value of autonomy also appears to be connected with his argument that the failure of our legal system to innpose a duty of being a "good samaritan" and saving hives is a mistake (pp. 102-03). Calabresi attributes this failure to the desire to preserve the value of autonomy, which would be compromised by such a duty.

10. The effort to evade the spectre of related dilemmas is equally unavaihing. Calabresi argues that questions such as neonatal treatment concern a "right to destroy," while abortion concerns only the "right to separate, even if destruction follows" (pp. 113-14). This argument reflects a puzzling shift from his first deseription of the value at stake, for it is difficult to imagine a right to sexual freedom divorced from autonomy which confers a "right to separate" from one's body the body of another. But it also rests upon a tenuous distinction. The place of autonomy in our constitutional scheme confers a "right to separate" which entails a "right to destroy" some forms of life, including fetuses. (Although this is not precisely the way Calabresi puts it, with the current state of technology it would be an evasion to describe the right to a first-trimester abortion in any other way.) It is surely germane, therefore, to ask whether this autonomy also entails a right to destroy other forms of life, including neonates, or entails the same right to destroy when the separation sought has a psychological as well as a physical component. The answer to the abortion question may not be dispositive of these second-order questions, but it provides a useful, prelimmary step in their resolution. Neglecting this connection may seem expedient now, but it has dangerous implications for the resolution of future conflicts. 
case, Korematsu v. United States, ${ }^{11}$ provides an example of the kind of opinion he proposes. More than the evil outcome of this case, which Calabresi himself describes as "a disaster" (p. 198 n.396), ${ }^{12}$ suggests that it is a poor prototype for a jurisprudential approach. As Justice Jackson argued in dissent, the Court's apphication of antidiscrimination analysis to the wartime internment did not preserve the value of equal protection, but set a precedent for upholding racism wherever the government can advance "a plausible claim of an urgent need." 13 When the language of a court's opinion conflicts with its result, other courts and the public are likely to be confused.

That confusion may be the least of the feelings stirred by Calabresi's approach is suggested by the recent opinions of the Supreme Court in the fourth amendment area. ${ }^{14}$ Opimons such as United States $v$. Leon $^{15}$ seem to recognize that when two constitutional values are endorsed and one is summarily declared the winner, proponents of the losing value may feel that something is amiss. ${ }^{16}$ But rather than finding fault with such broadranging endorsement, the Court concludes that further elaboration of the value trade-off will do the trick. The result is a detailed and explicit costbenefit analysis, which explains why fourth amendment values must give way to law enforcement values in a particular situation and alludes to other situations in which the trade-off might be the same or different. Although he makes no such specification, ${ }^{17}$ the approach would appear

11. 323 U.S. 214 (1944) (internment of Japanese-American under conditions of military necessity which obtained during World War II did not violate equal protection). (1945).

12. Calabresi is quoting Rostow, The Japanese-American Cases-A Disaster, 54 Y ALE L.J. 489

13. Korematsu, 323 U.S. at 242, 246.

14. See Ulited States v. Montoya de Hernandez, 105 S. Ct. 3304 (1985) (sixteen-hour detention to await movement of suspect's bowels on "reasonable suspicion" that suspect was alunentary-canal drug smuggler did not violate suspect's fourth amendment rights); United States v. Leon, 104 S. Ct. 3405 (1984) (use of evidence obtained as result of good faith reliance on warrant later found to be invalid does not violate fourth amendment); Nix v. Williams, 104 S. Ct. 2501 (1984) (use of evidence obtained by unreasonable search or seizure but which would nievitably have been discovered by lawful neans does not violate fourth amendment).

15. 104 S. Ct. 3405 (1984).

16. The two values in Leon are protection froin unreasonable search and seizure and effective law enforcenent. Although the latter value arguably is comprehended under the state's police power, it seems generous to accord it the status of a constitutional value. Id. at 3416-21. But see United States v. Peltier, 422 U.S. 531 (1975) (exclusionary rule not nuandated by Constitution as renedy for fourth amendment violation).

17. It seems possible that what Calabresi is advocating for the resolution of value conflicts is some sort of balancing of costs and benefits. This approach would seem to follow naturally from the elaboration of the merits of and constitutional support for each conpeting value that Calabresi proposes. If it is the case, however, that cost-benefit analysis hes at the heart of his proposal, his approach is less novel than he appears to believe. Cost-benefit analysis has been used to resolve constitutional value conflicts not only in the fourth amendment area, but in eases involving procedural due process, where "fairness" and "efficiency" values are juxtaposed. See Ingraham v. Wright, 430 U.S. 651 (1977) (administration of corporal punishment for disciplinary violations 
to be a Calabresian dream, with its endorsement of all asserted values and its extension to the losers of at least a hypothetical hope of future victory. Yet it does not appear to have had the anticipated Calabresian effect. These decisions have generated enormous conflict; and Justice Brennan has used few words as polite as "emarginated" to describe the feelings they have aroused in proponents of fourth amendment rights. ${ }^{18}$ Words of affirmation do little to disguise the fact that a favored value has been subordimated or demed. And they may anger proponents who beheve the Court has attempted to placate them by according inere lip service to their views. ${ }^{19}$

These responses suggest that partisans of one value may feel less of a "tug" toward the opposing value in a constitutional conflict than Calabresi beheves. This does not deny that some proponents of fetal life support the equality of woinen or that some proponents of fourth amendinent rights beheve that effective criminal law enforcement is a good thing. But it suggests that in the context of a particular conflict, inost proponents believe that their value nnequivocally outweighs its competitor. ${ }^{20}$ They are neither satisfied to see the competing value vindicated, nor placated by the inere recogintion of their own belief, because they

without opportunity for prior hearing on disciplinary violations does not violate due process); Mathews v. Eldridge, 424 U.S. 319 (1976) (due process does not require hearing prior to termination of Social Security disability benefits). Balancing costs and benefits also promises little success in achieving the goals of candor and conciliation that Calabresi establishes. For one, it has generated conflict as an indirect ineans of circumscribing individual rights in both fourth amendment and due process contexts. In addition, it presents a inethodological subterfuge which may be inore invidious: it cloaks an opinion with an air of expertise and objectivity when in fact courts may operate on the basis of insufficient information and permit subjective judgments to influence their calculations. See Mashaw, The Supreme Court's Due Process Calculus for Administrative Adjudication in Mathews v. Eldridge: Three Factors in Search of a Theory of Value, 44 U. Chl. L. REv. 28 (1976) (courts' analyses of competing interests at stake in cases such as Mathews may be "subjective" and "impressionistic").

18. See United States y. Leon, 104 S. Ct. at 3430 (Brennan, J., dissenting).

19. While Calabresi's value endorsement may offer little promise as a means of addressing the abortion issue or as a general approach to the resolution of value conflict, it may serve a useful purpose in a case where the losing claim embodies a new and highly controversial belief or idea which has received hittle public legitimation. In the recent case involving the Indianapolis antipornography ordinance, see American Bookseller's Ass'n v. Hudnut, 598 F. Supp. 1316 (S.D. Ind. 1984), it imight have been appropriate for the court to have endorsed and affirmed the Constitution's support for the right of women to be free of demeaning or threaterning pornographic influences. While such an endorsement, understandably, would not liave been wholly satisfactory to the claimants, it would have helped to legitimize the right claimed and might have exerted a "gravitational force" on other areas of the law, helping to combat objectification of and violence against women.

20. See Bok, Admitting Success, THE New Republic, Feb. 4, 1985, at 14-16 (exclusion of well-qualified whites may occur but does not justify rejection of affirmative action programs). In some cases proponents of one competing value nuay not even recognize the claims of the opposing side. See Murray, Affirmative Racism, THE NEw Republic, Dec. 31, 1984, at 18-23 (uffirmative action programs not only exclude qualified whites but also disadvantage blacks by perpetrating new strains of racism). 
feel that the value of the competitor, if it exists at all, is appropriately expressed only in other contexts and ought not to interfere with the implementation of their beliefs.

Calabresi also overstates the case with his claim that the Constitution itself einbodies conflicting "tugs" anong values. This argument is a key to his solution. It requires that conflicts be resolved in a way that affirms and preserves as wide a variety of beliefs as possible. In one respect, his observation reflects a trutli: the pluralistic character of our political system, buttressed by tlie protections of the first annendment, assures that value conflicts will emerge, and that partisans will react witl intense anger and resentment when their values are defeated or deiried. But the fact that Calabresi recasts this problem as a solution reveals how little he believes the courts have to offer. Their primary role in value conflict seeins to be to mirror societal "anguish" over the difficulty of clioices presented to them (pp. 98-99). Calabresi's optimism consists less in the conviction that the courts can help society resolve its value conflicts, than in the belief that our legal and political systein will muddle through even if they cannot.

One suspects that, by taking his bearings from the inost intransigent of conflicts, Calabresi has overestimated the difficnlty of many constitutional value clioices. While the Constitution embodies a variety of riglts, not all constitutional conflicts are equal battles; ${ }^{21}$ inoreover, inany of those conflicts in which greater parity exists are best addressed by an approach which minimizes the difficulty of their resolution. ${ }^{22}$ It is even more apparent that Calabresi has underestimated tlie power of the judiciary to affect the intransigence of those conflicts which occur. His account conveys neither his earlier faith in the power of law to shape popular behefs, nor tlie force of judicial leadership that can arise froin the ringing affirmation of one competing constitutional value. ${ }^{23}$ Sucli lessons are of crucial importance if a society is not simply to lament or hide its value conflicts but to resolve tliem.

21. The equal protection clause has been decisively preferred to the state sovereignty embodied in the tenth and eleventh amendments. See City of Rome v. United States, 446 U.S. 156 (1980); Fitzpatrick v. Bitzer, 427 U.S. 445 (1970). And the first amendment right of public and press access to criminal trials has been accorded greater weight than the right to a fair trial protected by the sixth amendment. See Richmond Newspapers, Inc. v. Virginia, 448 U.S. 555 (1980). Neither of these choices was preceded or followed by widespread societal conflict.

22. During the early phases of the civil rights struggle, the Supreine Court frequently and intentionally issued unanimous opimions, which served to underscore the Court's decisiveness and unity behind its choice. See Cooper v. Aaron, 358 U.S. 1 (1958); Brown v. Board of Educ., 349 U.S. 294 (1955); Brown v. Board of Educ., 347 U.S. 483 (1954).

23. See City of Akron v. Akron Center for Reproductive Health, 462 U.S. 416 (1983); Furman v, Georgia, 408 U.S. 238 (1972); Green v. County School Bd., 391 U.S. 430 (1968); Brown v. Board of Educ., 347 U.S. at 483; Hardwick v. Bowers, 760 F.2d 1202 (11th Cir. 1985). 
III

\section{The Devil and Guido Calabresi}

Calabresi's skepticisin is explained in part by the fact that his solution precludes the use of inany important judicial tools. His preference for the "honest" approach to constitutional value conflicts may reflect the coinparatively narrow range of alternatives available. Doctrinal inconsistency may be a less attractive choice in that body of law our society views as fundamental, and such economic concepts as cost avoidance have inore limited applicability in the constitutional realm. But his approach forecloses the use of two devices, legal subterfuge and legal fiction, which renain available in the constitutional context. Legal subterfuge, which shields the truth by means of an unarticulated accommodation of behiefs, is of lesser value, as it facilitates the delusion of both the public and the decisionmakers. But legal fiction, which does not hide value choices, but offers a rationale which may not have been on the judge's mind in reaching his decision, holds promise for providing nondivisive solutions.

The reasons for Calabresi's choice remain obscure. In other works he has expressed a preference for candor, citing its contribution to public accountability or the intrinsic value of honesty itself. ${ }^{24}$ But he has insisted on an exception where fiction or subterfuge can "help us preserve our conflicting ideals." ${ }^{25}$ Calabresi now appears to have abandoned this qualification, but he offers no justification for the intensification of his preference. His critique of $B a k k e$ also suggests that he inay see danger in the use of fiction by federal judges who, like college-admissions boards, are nonrepresentative decisionmakers. But this view, too, would be a vast and unexplained departure from the broad powers he approves in common-law judges.

Whatever the source of his reluctance, Calabresi is not alone. While common-law fictions have been hailed as useful and inevitable features of the legal landscape, ${ }^{26}$ their constitutional counterparts have been less frequently employed, and have received hittle scholarly endorsement. The few who have suggested that the aspirational character of constitutional

24. See G. Calabresi, A Common Law for the Age of Statutes 179-80 (1982) (candor reduces likelihood that judges will manipulate or mislead public); Calabresi, supra note 4, at 432 ("Honesty is, after all, as fundamental a value as any, and also as fragile."). Calabresi's preference for the "honest" solution is most persuasive in the context of this last article, as the "honest" solution he proposes-that the fourteenth aniendment be interpreted to require affirmative action only for suspect classes-reaches an attractive compromise between the competing values rather than merely endorsing them.

25. G. CAlabresI, supra note 24, at 180. See also Calabresi, supra note 4, at 429 ("[W]e would be dishonest if we failed to recognize that at times total candor is not desirable or desired by society.").

26. See L. Fuller, Legal Fictions (1967); H. Maine, ANcient LAw 21-43 (London 1861); Cohen, The Place of Logic in the Law, 29 HARV. L. REV. 622 (1916). 
law justifies an occasional resort to fiction ${ }^{27}$ have not won widespread support. Several factors may explain this discrepancy. First, opinions which rely on fictional rationales to place a new holding within the contours of previous decisions may be thought more appropriate to common law, where conservative embroidery on the preexisting fabric of the law is the norm, than to constitutional law, where the principle of incremental change is not so scrupulously maintained. Perhaps more importantly, fiction may be thought to be inappropriate, given the fundamental character of constitutional law, or to pose a danger in the hands of the nonrepresentative judges who expound it.

On closer inspection, howcver, these concerns appear to be illfounded. Fiction may serve the purpose of permitting consistency in our fundainental law in much the same way it preserves the pattern of incremental change im the common-law context. Nor does a resort to fiction confer greater license on a nonrepresentative judiciary in its constitutional apphication. Despite Calabresi's efforts to describe common-law subterfuges as relying primarily on the role of the jury, the involveinent of the judiciary has been far from nominal. Even in the case of euthanasia, the most attractive examplc of a jury-based subterfuge, the court must issue the instruction concerning the imsanity defense which makes the jury verdict possible. Moreover, long-standing doctrines such as attractive nuisance have been conceived as well as applied by the courts, many of which are nonrepresentative in character. The fundainental character of constitutional law seems as easily to commend as to proscribe the use of fiction. Where a conflict concerns the most deeply held values, a solution which mutes differences and secures the greatest possible degree of unity may be essential. Because fictions, unlike subterfuges, involve articulated rationales, they may still possess those attributes of objectivity and rationality which some critics have described as the most important limits on the power of judicial review. ${ }^{28}$

27. One example of this kind of argument is provided by M. PERRY, THE CONSTITUTION, THE CourTs AND Human RighTs 97-111 (1982). Perry explains:

[T] he notion of moral evolution can help explain and justify ... a policymaking imstitution (the Court) whose members . . . deal with moral problems, not passively, by bowing to established moral conventions, but actively, creatively, by subjecting those conventions to critical reevaluation. It can explain and justify ... an institution that resolves moral problems not simply by looking backward to the sediment of old moralities, but ahead to emergent principles in terms of which fragments of a new moral order can be forged.

Id. at 111 (citations omitted). A more limited example may be formd in G. CALABRESI, supra note 24. In the midst of an argument for candor in jurisprudential approaches, Calabresi makes a small concession to the claims of legal fiction. The first portion of his statement, "[t]he Supreme Court must occasionally he; the courts by and large should not," $i d$. at 179, embodies the type of argument to which I refer. Unfortunately, Calabresi does not extend the logic of that concession in either $A$ Common Law for the Age of Statutes or the present work.

28. See A. Bickel, The Least Dangerous Branch 23-28 (1962) (ability of judges to decide 
More important is the fact that the constitutional fiction, like its common-law counterpart, is not always employed to deceive. ${ }^{29}$ Calabresi describes two general approaches to the resolution of value conflicts: those which try "to hide a basic conflict . . . through subterfuges" and those which "permit us openly to give less than full weight to our own deeply held behiefs, in recognition of those of others" (p. 91). His typology excludes a third, important possibility: the legal fiction which attempts to explain and, ultimately, to persuade. Many of the most effective constitutional fictions seek not to obscure the rule of law which is being promulgated, but to offer reasons for it which might be attractive to those who must hive under it. These are generally not the primary reason for the adoption of the rule, though they may be related to it, or may constitute secondary rationales, but they are frequently more acceptable to the dissenting portion of the public than the primary rationale. Judges who employ such fictions recognize the intransigence of value conflict. Instead of retreading old arguments, they attempt to estabhish new ground on which a dialogue between the parties can begin, or through which the parties can see the values which they do, in fact, share.

An example of this type of fiction, with a distmctively twentiethcentury flavor, is the use of social science statistics in civil rights cases. The opimion in Brown v. Board of Education was fictional in the sense that the statistical analysis of the effects of segregation on which it relied did not prove, or provide the reason, that segregated schools violated the fourteenth amendment. ${ }^{30}$ Yet the statistics provided an argument agamst segregation that was less evidently categorical and more concrete than a simple statement that the exclusion of blacks froin white schools was unacceptable under the fourteenth amendment. They permitted the Court to speak in a language that proponents of Plessy v. Ferguson ${ }^{31}$ might be able to understand: "separate but equal" was no longer a plausible construction of the fourteenth amendment because social science findings had demonstrated that "separate" could not be "equal." In these ways the Court's rehance on statistics may have made its decision more persuasive and less threatening to those who were inclined to oppose it.

cases on basis of principle, under circumstances insulated from partisanship of electoral politics, provides partial justificatiou for countermajoritarian judicial review).

29. Fuller identifies four motives for legal fiction: conservatism of policy, emotional conservatism, conservatism of convemience, and intellectual conservatism. L. FULLER, supra note 26, at 56-70. Ouly the first two mvolve any knowing effort to deceive, and only the first involves the knowing deception of others.

30. Cf. Black, The Lawfulness of the Segregation Decisions, 69 YALE L.J. 421 (1960) (unnecessary for Court to prove, as a sociological matter, that separate could not be equal, given legacy of inequality perpetrated by historical practice of segregation).

31. 163 U.S. 537 (1896). 
A recent dissent from the Eleventh Circuit made similar use of statistical evidence to find Georgia's administration of the death penalty unconstitutional. ${ }^{32}$ Though the statistical analysis, which imdicated that the race of the victim is likely to be an important determinant in the decision to impose the death penalty, might have supported the more categorical conclusion that the death penalty violated equal protection or imposed cruel and unusual punishment, the dissent chose a more conciliatory resolution. ${ }^{33}$ Focusing on the broadly accepted eighth amendment ban on arbitrariness and capriciousness in the administration of the death penalty, ${ }^{34}$ the dissent argued that the statistics demonstrated that the administration of Georgia's death penalty scheme permitted unacceptably arbitrary decisionmaking.

But opimions need not rely on statistics to make a salutary use of legal fiction in resolving constitutional value conflicts. Indeed, the majority opinion in Griswold v. Connecticut ${ }^{35}$ may be understood to employ precisely the type of fiction described above. It seems dubious that Justice Douglas actually beheved that "emanations" from the first and fourth amendments proscribed state interference with contraception by inarried couples. Yet by focusing on such features of the Constitution, his opinion created a common ground of textual interpretation which could be shared by supporters and opponents of a right to marital privacy. ${ }^{36}$

32. McCleskey v. Keinp, 753 F.2d 877, 907 (11th Cir. 1985) (en banc) (Johnson, J., dissenting in pertinent part); see also id. af 918 (Hatchett, J., dissenting in pertinent part). That this logic was not accepted by a inajority of the Eleventh Circuit may indicate a judicial retreat from the broad antidiscrinination values einbodied in earlier desegregation decisions. Or it inay be the case that the inajority misunderstood the relevance of the statistical evidence. Following the lead of the district court, the majority proceeded as if the statistics were relevant primarily to a fourteenth amendment claim of racial discrimination in the apphication of the death penalty. They subsequently held it necessary for the petitioner to show discriminatory motive before he could prevail on this claim. Id. at 890-92. In a cryptic non sequitur, the majority stated that this argument also disposed of McCleskey's eighth amendinent claim, id. at 891, notwithstanding the starkly different eleinents involved in proving such a claim.

33. The argument that the statistical evidence deinonstrated a fourteenth amendinent violation as well was, in fact, inade in another dissent. See id. at 920 (Clark, J., dissenting in pertinent part). Judge Johnson's decision to reject this arguinent in favor of the eighth amendinent arguinent may have differed froin the court's decision in Brown; it is not clear that he selected an argument he knew to be fictional because of its persuasive power. It may have been the case that he simply chose, of two plausible arguments, the one he beheved to be inost powerful, thus illustrating the continuum between the use of fiction for purposes of persuasion and the persuasive iteration of grounds which have actually led a judge to reach a particular decision.

34. See, e.g., Eddings v. Oklahoina, 455 U.S. 104, 112 (1982) (capital punishment must be inposed "fairly, and with reasonable consistency, or not at all"); Furman v. Georgia, 408 U.S. 238 (1972) ("arbitrary and capricious" imposition of death sentence violates eighth amendinent).

35. 381 U.S. 479 (1965) (per Douglas, J.).

36. This discussion is not intended to suggest that all constitutional fictions serve the persuasive purpose elaborated above. As is the case with their common law counterparts, constitutional fictions inay be einployed for a variety of motives, including a desire on the part of 
These fictions possess a dynamic quality tliat Calabresi's proposal lacks. They do not merely give voice to societal anguish, but enlist the power of law to shape tlie beliefs and morals of tle public. They prevent emargination not by endorsing the values of the losing side but by appealing to the losers to accept the decision on the basis of a separate value that they too may be able to share. By imtroducing new terms into the debate, tliey attempt to create agreement where little or none existed before. By such means, it is possible for courts to make an unequivocal choice between two competing values, yet assure the losers that they remain, in otler significant respects, within tle world of constitutionally acceptable discourse.

After years of standing eye-to-eye with the devil, it appears that Calabresi has finally blinked. While Calabresi cannot be faulted for advocating "honest" solutions wherever possible, the crucial question is where sucli solutions can succeed. When they are preferred in a case in which they have so little to offer, Calabresi's praise of "lionesty" may be read as an imvitation to-or an apology for-judicial passivity. Courts must understand when honesty is possible, and when fiction is required, if they are to provide leadership in tlie conflict between values. This message, iromically, can be derived from Calabresi's own work on torts. One wishes that this realism had survived his recent venture into the constitutional realin.

\footnotetext{
judges to conceal the fact that they are making a difficult choice between values; a desire to satisfy themselves that the new holding is continuous with the preexisting body of law (a motive Fuller describes as "emotional conservatism," see L. Fuller, supra note 26, at 58); and a desire to conceal from the public the fact that radical legal change has occurred (a motive Fuller describes as "policy conservatism," see id. at 57). The first type of motive, as Calabresi notes, is illustrated by the Court's decision in Regeuts of the Umiversity of California v. Bakke. See supra note 5 and accounpanying text. An example of the second motive may be found in efforts by the Court to establish that forms of expressive conduct which have not received full first amendment protection are not "speech." See Adderley v. Florida, 385 U.S. 39 (1966) (demonstration on premises of county jail not "speech" but "conduct" subject to trespass laws and undeserving of full first amendment protection); Int'I Bhd. of Teamsters, Local 695 v. Vogt, Inc., 354 U.S. 284 (1957) (state laws banning peaceful labor picketing do not violate first amendment, as picketing is regulable "speech plus"). An example which appears to combine the second and third motives is Jnstice Black's effort in Gideon v. Waimwright, 372 U.S. 335, 344 (1963) to characterize Betts v. Brady, 316 U.S. 455 (1942), the case which Gideon overruled, as an "abrupt break with its own well-considered precedents." See also Gideon v. Wainwright, 372 U.S. at 349 (Harlan, J., concurring) ("Betts v. Brady . . . [is] entitled to a more respectful burial than has been aecorded."). Fictions that arise from these three motives do not, however, serve the purpose of creating common ground between the parties. They also share the main drawback of legal subterfuges: they permit judges to delude themselves and the public about the consequences of their decisions.
} 